\title{
COMMITMENT OF PRINCIPAL IN IMPLEMENTING TASKS IN HIGH SCHOOL FIRST STATE IN PADANG
}

\author{
Syahril
}

\begin{abstract}
Commitment is the principal determinants of success in leading a school. This study aims to determine the work commitments Head Junior High School in the city of Padang in performing the task. This study was a descriptive one. The study population was the Head Junior High School in the city of Padang. The research instrument used in the form of Likert Scale questionnaire. Data processing is done by finding the average score. The results of data processing show that affective commitment in carrying out the task of the principal is quite high with an average score of 3.83 out of a scale of 5 , meaning that the principal has had affective commitment in carrying out the task. Commitment to continuous, with an average of 4.12 means that in performing principals already have a continuous commitment. While the average scores for normative commitment is 4.02 this means that the principal also has a normative commitment in carrying out the task. In general it can be concluded that the Head of State Junior High School in Padang has had a fairly high work commitment in carrying out the task with an average score of 3.99. But still need to be refined and improved.
\end{abstract}

Keywords: Commitment; affective, berketerusan, normative and principals 


\section{Pendahuluan}

Banyak hasil penelitiaan menunjukkan bahwa pendidikan merupakan faktor penentu kemajuan suatu bangsa, jika suatu bangsa berhasil meletakkan dan membangun dasar-dasar pendidikan kebangsaannya dengan baik, maka akan memberi pengaruh yang besar terhadap kemajuan pada bidang-bidang lain. Keberhasilan di bidang pendidikan dipengaruhi atau ditentukan oleh banyak faktor, salah satunya adalah faktor kepala sekolah. Yukl, 2006 dan Kouzes Posner, 2003 mengemukakan kepala sekolah sebagai pemimpin di sekolah merupakan unsur utama yang amat menentukan kejayaan dan keberhasilan suatu sekolah. Kualitass sekolah sangat bergantung kepada kualitas pimpinan (kepala) pada sekolah tersebut. Hussien, 2007, mengemukakan kepala sekolah merupakan faktor penentu terhadap kecermelangan dan keberhasilan suatu sekolah. Hal ini juga disokong oleh Levin dan Lockheed (2001), yang mengatakan bahwa maju dan mundurnya sebuah sekolah sangat ditentukan oleh kualitas kepemimpinan kepala pada sekolah tersebut. Oleh karena itu, tidak ada sekolah yang menjadi maju dan cemerlang sekiranya kepemimpinan kepala sekolah pada sekolah tersebut lemah atau tidak berkualitas (Dessler, 2005). Sebaliknya sekolah yang lemah dapat bertukar menjadi sekolah yang berkesan dan berprestasi dengan adanya kepemimpinan kepala sekolah yang berkualitas, (Hussien, 2007).

Sebagai pimpinan di sekolah kepala sekolah memiliki beberapa peran dalam melaksanakan tugas yaitu sebagai educator, maneger, administrator, supervisor, lieder, inovator dan motivator (Mulyasa, 2013). Keberhasilan atau kesuksesan kepala sekolah untuk melaksanakan tugas dan peran tersebut dipengaruhi oleh banyak faktor, satu dari faktor tersebut adalah komitmen kerja kepala sekolah dalam melaksanakan tugas pada sekolah yang dipimpinnya.

Komitmen kerja merupakan faktor penentu kejayaan dan keberhasilan kepala sekolah dalam memimpin sekolah. Newstrom (2007) mengatakan komitmen kerja dapat diartikan, sebagai kesetiaan pegawai terhadap sejauh mana tingkat pengenalan diri pegawai pada pekerjaan dan keinginan-keinginannya untuk meneruskan penyertaan aktifitasnya dalam organisasi dimana dia berada. Sedangkan Feldman (2000) menyatakan, bahwa komitmen kerja adalah kecenderungan seseorang untuk melibatkan diri ke dalam apa yang dikerjakan dengan keyakinan bahwa aktifitas yang dikerjakan penting dan bermakna. Kedua pendapat di atas pada dasarnya mempunyai pandangan yang sama tentang komitmen yaitu fasa atau tingkat keterikatan pegawai terhadap tugasnya. Sementara itu, Greenberg dan Baron (2009) berpendapat bahwa komitmen organisasi adalah sikap konsisten individu terhadap organisasi di mana mereka bekerja. Sikap tersebut adalah sikap konsisten individu terhadap keterlibatannya dengan pekerjaan atau tugas yang menjadi tanggungjawabnya dan mereka tertarik untuk mempertahankan pekerjaan dan tugas mereka tersebut. Sejalan dengan itu Anthony (2009) mengemukakan komitmen kerja adalah adalah penerimaan seseorang terhadap nilai pekerjaan atau bidang pekerjaan yang dipilihnya, 
dan keinginan nutuk mempertahankan kedudukan dalam tugas tersebut. Komitmen ada ketika manusia mempunyai peluang untuk menentukan apa yang akan dilakukan. Komitmen terhadap pekerjaan dikonseptualisasikan sebagai hubungan psikologi antara orang dan pekerjaan yang terlibat berdasarkan pada reaksi afektif terhadap pekerjaan itu. Robbins (2003) mengemukakan orang yang mempunyai komitmen terhadap pekerjaan, akan bekerja secara total dalam organisasi dengan memberikan segenap perhatian, fikiran, tenaga dan masa yang dimilikinya untuk bekerja sehingga mencapai hasil yang optimum. Sebaliknya orang yang tidak mempunyai komitmen, meskipun dia mempunyai kompetensi yang bagus, dia akan bekerja setengah hati. Komitmen mempunyai hubungan dengan kesetiaan, ketaatan dan kepuasan kerja dalam organisasi. Orang yang berkomitmen tinggi lebih mementingkan pekerjaan dan tugas dalam memenuhi kebutuhan organisasi berbanding kebutuhan atau keperluan pribadi.

Orang yang memiliki komitmen kerja menurut Goleman (1999) mempunyai ciri-ciri sebagai berikut (a) mempunyai inisiatif untuk mengatasi masalah yang muncul, baik yang berhubungan atau berkaitan secara langsung dengan dirinya mahpun yang terkait dengan kelompok atau perkumpulannya, (b) bernuansa emosional, yaitu membuat sasaran individu dan sasaran organisasi menjadi satu atau sama sehingga mereka merasakan keterikatan yang kuat terhadap organisasi atau pekerjaannya, (c) bersedia melakukan pengorbanan atau berkorban untuk kepentingan tugas atau organisasi apabila diperlukan, (d) mempunyai visi strategik yang tidak mementingkan diri sendiri, (e) bekerja secara sungguh-sungguh walaupun tanpa ganjaran atau imbalan secara langsung, (f) merasa sebagai pemilik atau memandang diri sebagai pemilik sehingga setiap tugas diselesaikan secepat dan sebaik mungkin, (g) mempunyai rumusan misi dan visi yang jelas sebagai gambaran terhadap apa yang akan dicapai, dan (h) mempunyai kesadaran diri dengan perasaan yang jernih bahwa pekerjaan bukanlah suatu beban, tetapi merupakan kesenangan atau hobi yang dilakukan. Ciri-ciri di atas merupakan penentu bahwa pada diri seseorang terdapat komitmen dalam melaksanakan pekerjaan. Sementara itu Joseph (2002) mengemukakan beberapa ciri-ciri orang yang mempunyai komitmen kerja dalam organisasi yaitu, (a) mempunyai kepercayaan dan sokongan yang tinggi terhadap nilai dan pekerjaan, (b) mempunyai keinginan berusaha yang sungguh-sungguh untuk melaksanakan pekerjaan dalam organisasi, (c) mempunyai keinginan untuk melaksanakan kerja dengan baik dan memelihara keahlian organisasi, (d) mempunyai keinginan kuat untuk tetap jadi anggota organisasi, (e) kesediaan untuk tetap berusaha sebaik mungkin demi kepentingan organisasi, dan (f) kepercayaan dan penerimaan yang kuat terhadap nilai dan tujuan organisasi.

Hasil penelitian Nurliana (2011), mendapati bahwa komitmen kerja kepala sekolah dalam melaksanakan tugas pada lingkungan Kementerian Pendidikan Nasional khususnya kepala sekolah dasar diwilayah Kota Palembang masih dalam katagori rendah. Sedangkan Imam Subandi (2012), menyatakan bahwa komitmen kerja kepala sekolah dalam melaksanakan tugas masih jauh dari yang diharapkan. Rendahnya 
komitmen kerja kepala sekolah dalam melaksanakan tugas terlihat dari kurangnya kerjasama pada sekolah yang dipimpinnya, rendahnya tanggungjawab dan kurangnya disiplin kepala sekolah dalam melaksanakan tugas. Seperti kerap atau seringnya kepala sekolah meninggalkan sekolah untuk melakukan pekerjaan yang kurang terkait dengan tugasnya di sekolah, kurangnya pengawasan dan pembinaan yang mereka lakukan baik terhadap pesera didik atau pelajar maupun terhadap guru sehingga kerap atau sering terjadi konflik di sekolah, rendahnya disiplin di sekolah, hasil belajar siswa masih belum mencapai standar yang diharapkan. Akibat dari permasalahan tersebut (rendahnya komitmen kerja kepala sekolah sekolah) kerap atau sering terjadi demontrasi atau unjuk rasa yang dilakukan guru dan siswa, mereka menuntut agar kepala sekolah mundur dari kedudukannya atau berhenti daripada kepala sekolah, (Wahjosumidjo 2013). Hal tersebut jelas akan mengganggu kenyaman kegiatan pembelajaran dan keberhasilan penyelenggaraan pendidikan di sekolah untuk itu komitmen kerja kepala sekolah dalam pengurusan dan pengelolaan sekolah harus ditingkatkan.

Komitmen kerja kepala sekolah yang dimaksudkan pada penelitian ini adalah keterikatan emosional kepala sekolah dengan pekerjaan yang menjadi tanggungjawabnya. Komitmen kerja tersebut diukur berdasarkan aspek komitmen afektif, komitmen kontinu (berkelanjutan) dan komitmen normatif, (Allen dan Meyer 2002). Komitmen afektif berkaitan dengan keterikatan emosional, identifikasi dan keterlibatan kepala sekolah pada pekerjaannya dalam organisasi. Kepala sekolah yang memiliki komitmen afektif yang kuat akan terus bekerja dalam organisasi karena mereka memang ingin (want to) untuk melakukan pekerjaan tersebut. Komitmen kontinu (berkelanjutan) berkaitan dengan pertimbangan untung rugi dalam diri kepala sekolah untuk tetap bekerja atau meninggalkan pekerjaan. Kepala sekolah yang bekerja berdasarkan komitmen berkelanjutan akan bertahan bekerja dalam organisasi untuk melaksanakan pekerjaan sebab mereka ingin (need to) untuk melakukan hal atau pekerjaan tersebut karena tidak ada pilihan lain. Sedangkan komitmen normatif berkaitan dengan perasaan wajib untuk tetap (kekal) bekerja dalam organisasi. Kepala sekolah yang memiliki komitmen normatif yang tinggi merasa bahwa mereka wajib (ought to) untuk bekerja, kerana dengan bekerjalah mereka dapat memenuhi keperluannya.

\section{Metodologi}

Penelitian ini hanya berbentuk deskriptif. Populasi penelitian adalah kepala sekolah pada Sekolah Menengah Pertama (SMP) Negeri di Kota Padang yang berjumlah sebanyak 37 orang. karena populasi tidak begitu banyak atau besar (hanya 37 orang), maka pada penelitian ini tidak dilakukan pengambilan sampel, dengan lain kata semua populasi dijadikan responden pada penelitian ini.

Pengumpulan data dilakukan dengan menggunakan instrumen dalam bentuk angket yang disusun berdasarkan Skala Likert. Jumlah item angket untuk mengukur 
komitmen kerja kepala sekolah sebanyak 32 item, dengan rincian angket untuk mengukur komitmen afektif sebanyak 11 item, angket untuk mengukur komitmen berketerusan sebanyak 11 item, dan angket untuk mengukur komitmen normatif sebanyak 10 item.

Hasil uji coba terhadap instrumen didapatkan data bahwa instrumen yang digunakan pada penelitian ini memiliki tingkat validitas dan reabilitas yang cukup tinggi dengan Alfa Cronbanch $\alpha_{0,96}$. Sedangkan pengolahan data pada penelitian ini hanya dilakukan dengan mencari rata-rata skor dari masing-masing aspek yang diukur yaitu aspek komitmen afektif, komitmen kontinu (berkelanjutan) dan komitmen normatif.

\section{Hasil penelitian dan Pembahasan}

Hasil penelitian yang telah dilakukan tentang komitmen kerja kepala sekolah pada Sekolah Menengah Pertama (SMP) Negeri di Kota Padang, menunjukkan bahwa komitmen kerja kepala sekolah sudah cukup tinggi, baik pada aspek komitmen afektif, komitmen kontinu (berkelanjutan), maupun pada aspek komitmen normatif. Untuk lebih jelasnya dapat dilihat pada tabel berikut.

Tabel 1. Dapatan Kajian tentang Komitmen Kerja Kepala Sekolah

\begin{tabular}{|c|l|c|}
\hline No & \multicolumn{1}{|c|}{ Bentuk Komitmen Kerja } & Rata-rata skor \\
\hline 1 & Komitmen afektif & 3,83 \\
\hline 2 & Komitmen kontinu (berkelanjutan) & 4,12 \\
\hline 3 & Komitmen normatif & 4,02 \\
\hline & Rata-rata total & 3,99 \\
\hline
\end{tabular}

Data pada tabel di atas, menunjukkan bahwa komitmen afektif kepala sekolah yang terkait dengan keterikatan emosional, identifikasi dan keterlibatannya untuk melaksanakan pekerjaan dalam organisasi cukup tinggi, dengan rata-rata skor 3,83 artinya kepala sekolah telah memiliki komitmen afektif dalam melaksanakan tugas. kepala sekolah yang memiliki komitmen afektif yang tinggi dalam melaksanakan pekerjaan akan terus bekerja dalam organisasi, hal ini disebabkan karena mereka memang ingin (want to) untuk melaksanakan melakukan pekerjaan tersebut, Greenberg dan Baron (2009).

Komitmen kontinu (berkelanjutan) dengan rata-rata skor 4,12. Hal ini berarti kepala sekolah pada Sekolah Menengah Pertama Negeri Kota Padang sudah memiliki komitmen berkelanjutan dalam melaksanakan tugas. Komitmen berkelanjutan berkaitan dengan pertimbangan untung rugi yang dirasakan atau didapatkan kepala sekolah untuk tetap bekerja atau meninggalkan pekerjaan. kepala sekolah yang bekerja berdasarkan komitmen berkelanjutan akan bertahan (tetap bekerja) dalam organisasi sebab mereka memang ingin (need to) untuk melakukan pekerjaan tersebut karena tidak ada pilihan lain. 
Sedangkan rata-rata skor untuk komitmen normatif kepala sekolah dalam melaksanakan tugas adalah 4,02 ini juga mempunyai arti bahwa kepala sekolah juga sudah memiliki komitmen normatif dalam melaksanakan tugas. Komitmen normatif berkaitan dengan perasaan, nilai-nilai ataupun norma yang ada pada diri kepala sekolah untuk tetap (kekal) menjadi bahagian daripada pekerjaan karena bekerja merupakan kewajiban yang harus dilakukan kepala sekolah. Berdasarkan hasil penelitian ini dapat disimpulkan bahwa pada umumnya kepala sekolah pada Sekolah Menengah Pertama (SMP) Negeri di Kota Padang telah memiliki komitmen yang cukup tinggi dalam melaksanakan pekerjaan.

Meskipun hasil penelitian ini menunjukkan, bahwa pada umumnya kepala sekolah pada Sekolah Menengah Pertama (SMP) Negeri Kota Padang telah memiliki komitmen yang cukup tinggi dalam melaksanakan pekerjaan, namun masih perlu disempurnakan atau ditingkatkan agar kesuksesan atau kejayaan pada sekolah yang dipimpinnya dapat dicapai, baik pada aspek komponen komitmen afektif, kontinu (berkelanjutan) maupun pada aspek komitmen normatif.

\section{Kesimpulan}

Berdasarkan dapatan pada penelitian ini dapat disimpulkan bahwa komitmen kerja kepala sekolah pada Sekolah Menengah Pertama (SMP) Negeri Kota Padang sudah cukup tinggi, namun masih belum memuaskan dan masih perlu disempurnakan dan ditingkatkan lagi, baik dari aspek komitmen afektif, komitmen kontinu (berkelanjutan) maupun pada aspek komitmen normatif. Penyempurnan dan peningkatan ini dilakukan untuk mencapai kejayaan dan kesuksesan pada sekolah yang dipimpinnya, sebab mustahil kejayaan dan kesuksesan pada suatu sekolah akan tercapai kalau kepala sekolah yang memimpin sekolah tersebut tidak atau kurang memuliki komitmen dalam melaksanakan tugas. 


\section{Rujukan}

Anthony, Gary Dworkin. (2009). International Handbook of Research on Teachers and Teaching. New York: Springer.

Dessler, Garry. (2005). Manajemen Personalian (terjemahan Agus Dharma). Edisi Ketiga. Jakarta: Erlangga.

Feldman, Robert S. (2000). Adjustment Applying Psychology in a Complex Word. New York: McGraw-Hill Book Company.

Greenberg, Jerald and Robert A. Baron. (2009). Behavior in Organizations. Upper Saddle River. New Jersey: Pearson Education, Inc.

Goleman, Daniel. (1999). Kecerdasan Emosi untuk Mencapai Puncak Prestasi. Terjemahan Alex Tri Kantjono Widodo. Jakarta: Gramedia.

Hussein Mahmood. (1997). Kepemimpinan dan Keberkesanan Sekolah. Kuala Lumpur: Dewan Bahasa dan Pustaka.

Imam Subandi. (2012). Pengaruh Komitmen Tugas, Pemberdayaan dan Motivasi Kerja terhadap Kinerja Pengawas Sekolah. (disertasi). Jakarta: Pasca Sarjana UNJ.

Joseph, Linz Susan J. (2002). Job Satisfaction Among Russian Workers. William Davidson Institute Working Paper, Reseacrh Feelow Wlliam Davidson Institute University of Michigan.

Kouzes, James M., Barry Z. Posner. (2003). Leadership the Challenge. San Francisco: Jossey-Bass, A Wiley Imprint.

Lockheed, ME \& Levin HM. (2001). Creating Effective Schools. Edisi. Washington DC: Falmer Press.

Mulyasa. (2013). Kepala sekolah yang Profesional. Bandung: Alfabeta.

Newstrom, John W. (2007). Organizational Behavior. Human Behavior at Work. New York: McGraw-Hill.

Nurliana. (2011). Pengaruh Budaya Organisasi, Kepemimpinan, Kepuasan Kerja dan Motivasi Berprestasi terhadap Komitmen Organisasi Kepala-kepala SDN di Kota Palembang. (disertasi). Jakarta: Pasca sarjana UNJ.

Robbins, Stephen P. (2003). Organizational Behavior. New Yersey: Prentice-Hall International, Inc.

Wahjosumidjo. (2013). Kepemimpinan Kepala Sekolah. Jakarta: Raja Grafindo Persada.

Yukl, G., \& Michel, J. (2006). Proactive Influence Tactics and Leader-Member Exchange. In C. A. Schriesheim and L. Neider (Eds.). Power and Influence in Organizations: Research in Management. Greenwich, CT: Information Age Publishing. 